\title{
“LET ME TELL YOU...": AUDIENCE ENGAGEMENT STRATEGIES IN THE CAMPAIGN SPEECHES OF TRUMP, CLINTON, AND SANDERS
}

\author{
Justin Quam, Marianna Ryshina-Pankova \\ Georgetown University \\ $37^{\text {th }}$ and O Streets, N.W., Washington D.C. 20057, USA
}

\begin{abstract}
Throughout the 2016 campaign, presidential candidate Donald Trump surprised observers with his ability to maintain his popularity in the face of unorthodox and often offensive statements. Trump likely bolstered his electoral chances by appealing to a large segment of voters with whom other candidates failed to align themselves. To quote one news anchor, "People tried to attack Trump; it just didn't work voters liked him anyway". As previous work by Miller $(2002 ; 2004)$ has shown, systemic functional linguistic (SFL) analysis (Halliday \& Matthiessen, 2004) can illuminate particular strategies politicians employ to strengthen their arguments and exhort their audiences to join their efforts. In this paper, we employ the SFL-based Engagement framework (White, 2003; Martin \& White, 2005) to examine ways in which the 2016 presidential candidates aligned themselves with their audiences. Our analysis of the speeches of Donald Trump, Hillary Clinton, and Bernie Sanders reveals markedly different patterns of interaction with the voters in terms of ways expansive and contractive dialogic strategies are used, an intended audience is identified and thematized, and shared assumptions are made. While Trump makes his arguments in a highly constrained dialogic space, taking the agreement with the audience for granted, his opponents often employ a mix of contractive and expansive argumentative strategies and make more explicit overtures to the audiences whose perspectives they share. This study offers insights as to how each candidate identifies and addresses his or her ideological sympathizers or opponents and exhorts the former to intensify their support.
\end{abstract}

Key words: discourse analysis, political discourse, political speeches, dialogue space communication strategies

\section{INTRODUCTION}

Donald Trump's electoral victory has already sparked much soul-searching on a wide array of topics, from the empirical (the reliability of political forecasting) and the ideological (the disconnect between parties' platforms and the beliefs of their core supporters) to the rhetorical (the relevance of debates and advertisements). Most political analysts predicted, after he had announced his candidacy, that Trump's support would collapse during the primary season (Silver, 2015) for reasons that seemed logical at the time: He was the first major party nominee since 1952 to have had no previous political experience; he won the nomination despite well-documented apostasies on core Republican issues (Bierman, 2016); and his bare-bones organization eschewed the data analysis and voter contact apparatus of a typical campaign (Parker \& Haberman, 2016). His narrow victory throws the relevance of these points into question and demands a wide-ranging effort to understand his appeal.

The hallmark of Trump's campaign was the rally speech. Rather than devote his time to meeting individual constituents and interest groups, Trump addressed large 
crowds with off-the-cuff, tangential speeches, during which he discussed topic after topic in meandering fashion. These addresses departed from the well-established patterns of the political speech in terms of both rhetorical style and content. During the primary, Trump often made statements that went well outside the political mainstream yet seemed to increase his support. Among the strangest phenomena of the 2016 race was the disconnect between the horror of political pundits - who pronounced with almost comical frequency that Trump's unpolished remarks concerning Mexicans, Muslims, or women would cost him the nomination - and the favorable response of Trump supporters to unconventional and often unconstitutional proposals such as a religious test for immigrants. Throughout the primary and the general election, both pundits and politicians underestimated Trump's ability to drum up support through these atypical political speeches.

Since an election campaign is an example par excellence of 'doing things with words' (Austin, 1975), a canonical instance of the speech act intended to spur action on the part of the audience (Chang \& Mehan, 2006), we believe a linguistic investigation of Trump's speeches may throw light on how he achieves his communicative and political goals. Whereas linguists and political scientists with an interest in rhetoric have investigated presidential candidates' speeches for decades, tracking such formal features as lexical frequency, complexity, and pronoun use, in our study we take a functional approach and draw on the system of Engagement as proposed by Martin and White (Martin \& White, 2005; White, 2003, 2015). This framework allows us to focus on the semantic strategies that Trump uses to position himself and relate to the audience - and thus capture a greater range of linguistic features that realize these strategies.

In order to highlight the unconventionality of Trump's rhetorical style, we compare one of his primary election victory speeches to victory speeches by Secretary Hillary Clinton and Senator Bernie Sanders. While the focus on three speeches cannot yield conclusive results about the style and strategies of the presidential candidates, we believe that the analysis of these examples can suggest some salient patterns and differences in the ways the candidates chose to relate to their audience.

We begin by discussing existing commentary on the political discourse surrounding these three candidates. We then provide an overview of the Engagement approach to discourse analysis, sketch out the methodology of the current study, which was conducted just after the 2016 primary campaign concluded, and outline the findings of our analysis of Trump, Clinton, and Sanders's speeches. We conclude with preliminary thoughts as to why, in the political environment of 2016, Trump's particular style may have been well suited to persuade and engage a wide swath of Americans.

\section{PREVIOUS ANALYSES OF CANDIDATES' LANGUAGE}

The political speech is far from a novel subject for linguistic analysis. In recent decades, rhetorical and linguistic studies have gained the attention of political consultants and the public at large (Clark, 2007), with scholars such as Westen (2008) and Lakoff (2004) arguing that candidates' choice of linguistic frames can decisively alter an audience's response, to the degree that "specific words and phrases (...) have the ability to 
elicit core value systems" (Iyengar, 2005, p. 4). Numerous empirical studies have explored Lakoff's framework (see, e.g., Barreto, Redlawsk, \& Tolbert, 2009; Knoll, Redlawsk, \& Sanborn, 2011); Degani (2016b), for example, drew on Lakoff to analyze specific candidates' speeches, arguing that John McCain and Barack Obama's divergent ideological ways of seeing the world were expressed in the usage frequency of certain lexical items. Following the 2008 election, Barack Obama's obvious effectiveness as an orator provided data for semiotic and metaphorical analysis guided by Lakoff's work (Catalano, 2011), as did the sometimes racially charged language used by his critics (Sparks, 2009). Pennebaker, Slatcher, and their colleagues have also used the political speech in a broader, not exclusively political context to illustrate how the usage of lexical categories and types of verbs can contribute to a speaker's overall linguistic style (Slatcher et al., 2007) and how insights on speakers' psychological states might be gleaned by analyzing the usage of personal pronouns and emotionally weighted words (Pennebaker, Slatcher, \& Chung, 2005).

Trump's political language, however, seems to veer away from what observers of political discourse have come to expect: Speeches crafted by a team of professionals that express a coherent vision, repeat talking points that reflect party views, and explicitly appeal to a broad voter base. Instead, Trump's rally speeches meandered, to the extent that writers at the online news magazine Slate asked readers for crowd-sourced help in diagramming one of Trump's more rambling sentences (Lexicon Valley, 2015). Political analysts and linguists also struggled to parse Trump's syntax; Pullum (2015), for example, noted that the sentence in question "has no structure at all". In an interview with Vox, Pullum went so far as to claim that Trump's aversion to embedded clauses reflects an undisciplined mind:

When you say something like "While Congress shows no interest in doing X, I feel that the American people believe it is essential", the clause "it is essential" is inside the clause "the American people believe it is essential" which is inside the clause "I feel that the American people believe it is essential", and so on. You get no such organized thoughts from Trump. It's bursts of noun phrases, self-interruptions, sudden departures from the theme, flashes of memory, odd side remarks. (...) It's the disordered language of a person with a concentration problem (Golshan, 2016).

Other scholars, meanwhile, explain Pullum's observation by arguing that Trump's speeches are a better fit for oral genres (we don't normally speak using clauses like "while..."), while other politicians' speeches betray more linguistic markers characteristic of written genres - they are more compact, more organized, thought through in advance, for an audience that expects certain written-like conventions. If Trump's speeches are more suited to oral delivery, this may make them correspondingly difficult to render in prose (Libit, 2016). Liberman (2016a, 2016b) makes a similar point, arguing that while Trump's style differs from the norm of a political arena, it would be at home in a comedy club: "Donald Trump uses the style of a stand-up comic rather than the style of schoolteacher. But let's not pretend that the result is incoherent or unintelligible - it's just a skillful instance of human speech communication in its natural state" (2016a). Furthermore, in line with typical conventions of oral performances, Trump 
uses gesture in his speeches to mock, entertain, and show dominance, which has also been linked to his success (Hall, Goldstein, \& Ingram, 2016). Whatever the merits or deficiencies of Trump's approach, his addresses clearly depart from the mold of a political speech on many fronts, and we argue that it would not be pejorative to describe Trump's style as simpler than his opponents' communicative styles.

Clinton's and Sanders's long careers have also inspired linguistic analyses on a variety of topics. Anderson (2002), for example, found that Clinton employed what the author characterized as a more 'masculine' style in her 2000 run for the Senate, compared to her rhetoric as First Lady; Bligh et al. (2010) reported a similar result in Clinton's 2008 rhetoric. Degani (2016a) investigated both Clinton's and Trump's 2016 speeches through the lens of lexical frequency as related to the simplification of political rhetoric and construal of Self and Other. She concluded that Clinton uses significantly more complex language, while Trump's rhetoric relies more often on us-versus-them dichotomies.

Studies on Sanders tend to focus on his political views, but his rhetoric also provides plenty of grist for linguistic analysis; Wilz, for example, argues that Sanders was able to win more approving press coverage by adopting a more "hypermasculine" tone than Clinton, despite espousing very similar views (2016: 358). In her master's thesis, Hoel (2016) argues that Sanders exploited an inflection point in American politics by coopting "percentage talk" (2016: 37), rhetorically identifying himself and his supporters with "the 99\%" against an Other he refers to variously as "the 1\%", "the billionaire class", and "Wall Street", thereby adopting economic inequality as a core Democratic issue (see also Savoy, 2016).

An Engagement analysis of victory speeches by Trump, Clinton, and Sanders, presented below, revealed patterns in the ways the candidates appealed to their supporters and offered their audience opportunities to respond or identify with the speaker.

\section{THE PRESENT STUDY}

This study draws primarily on the Engagement system (Martin \& White, 2005), which provides a framework for analyzing how language users position themselves toward the subject under discussion and interact with an audience through alignment and disalignment strategies. As with other frameworks inspired by Halliday's systemic functional grammar (Halliday \& Matthiessen, 2004), the emphasis in the Engagement system is not on formal lexicogrammatical categories - e.g., pronouns, hedges, or mental verbs - but on the functional role of a given linguistic resource. We are interested here, in other words, in how language users can create solidarity with an audience and reveal their "attitudes towards the truth value of their propositions" (Simon-Vandenbergen, White, \& Aijmer, 2007: 33). The theory behind this framework draws on Bakhtin's suggestion that any utterance implicitly reacts to other previous speech; it "take[s] up in some way, what has been said/written before, and simultaneously (...) anticipate[s] the responses of actual, potential or imagined readers/listeners" (White, 2015). Engagement, in other words, allows linguists to analyze how language users respond to both explicit and implicit views of their audience (Martin \& White, 2005) and demonstrate 
solidarity and alignment not only with their ideological cohort, but also with those with whom they disagree (Miller, 2004). The Engagement framework is particularly suitable for the analysis of political speeches, often aimed at mobilizing a specific interest group or demographic, as it reveals how speakers appeal to their audience through "a set of micro-maneuvers by which different alignments or affiliations are envisaged with an array of different value positions" (White, 2003: 275).

Within the Engagement system, the most general differentiation is made between utterances that admit the possibility of a competing truth claim (considered heteroglossic) and those that do not (called monoglossic statements or bare assertions). In the most basic terms, the utterance "Kathryn Janeway is the best captain on Star Trek" would be monoglossic, while utterances that imply a possible rejoinder are heteroglossic:

- Jim Kirk is not the best captain on Star Trek. (This denial implies that it is possible to believe he is.)

- It is clearly beyond the shadow of a doubt that Kathryn Janeway is the best captain on Star Trek. (The very reference to doubt implies that there exists a counter-assertion to be argued against.)

Within the monoglossic statements, a further distinction is made between assertions that present the proposition as currently "at issue or up for discussion" (Martin \& White, 2005: 100), as in the examples above, and those that contain presuppositions formulated in a way that does not have an argument structure and "survives even under negation" (Simon-Vandenbergen et al., 2007: 35). The following headline illustrates the latter case:

"Barack Obama's Transformational Success is Only Beginning to Come into View". [Jonathan Chait, New York Magazine, 7/27/16]1.

The sentence is monoglossic, but while it might be challenged or qualified, e.g. -

Barack Obama's Transformational Success is NOT Beginning to Come Into View

- the controversial idea that Barack Obama has been successful in a transformational way has been nominalized, and as a result, it is not even open to question.

By choosing such formulations, speakers position their audience to treat their assertions as "generally known or agreed upon, and hence as uncontentious" (Simon-Vandenbergen et al., 2007: 32). Furthermore, statements with presupposition enable speakers to assert "solidarity in contexts where interactants already share a great deal of common ground and a common outlook. (...) [B]y encoding something as background, shared knowledge, the speaker at the same time presents a proposition as one whose truth is accepted by the hearer" (Simon-Vandenbergen et al., 2007: 46, 49). SimonVandenbergen and her colleagues label this mode of engaging with the reader as maximally restrictive - even more so than a bare monoglossic assertion because the speaker implicitly presents certain propositions as simply not arguable. At the same time, however, they may widen the circle of their supporters by identifying common ground on which they already agreed.

${ }^{1}$ http://nymag.com/daily/intelligencer/2016/07/obamas-success-only-beginning-to-comeinto-view.html. 
Heteroglossic engagement resources are further categorized as either dialogically expanding (entertain and attribute), which open up additional dialogic space with the introduction of potential new arguments, and contracting (disclaim or proclaim), which implicitly or explicitly reject alternative arguments (see Table 1). Together, the heteroglossic and monoglossic assertions map out a continuum of "theoretical possibility of alternative opinion" (Simon-Vandenbergen, White, \& Aijmer, 2007: 46), with contracting heteroglossic propositions implicitly allowing for more disagreement than monoglossic ones, but still actively closing off potential debate.

Table 1

Engagement System Network

\begin{tabular}{|c|c|c|}
\hline $\begin{array}{l}\text { Dialogic } \\
\text { Role }\end{array}$ & Type & Subtype \\
\hline \multirow[t]{3}{*}{ Expansive } & $\begin{array}{l}\text { Entertain: the author holds } \\
\text { out a dialogic alternative } \\
\text { as possible }\end{array}$ & \\
\hline & \multirow{2}{*}{$\begin{array}{l}\text { Attribute: the author posits } \\
\text { another voice as the source } \\
\text { of the assertion }\end{array}$} & $\begin{array}{l}\text { Distance: the author presents an external source's voice as } \\
\text { questionable }\end{array}$ \\
\hline & & $\begin{array}{l}\text { Acknowledge: the author presents an external source's voice } \\
\text { without explicit endorsement, leaving room for countervailing } \\
\text { views }\end{array}$ \\
\hline \multirow[t]{5}{*}{ Contractive } & \multirow[t]{2}{*}{$\begin{array}{l}\text { Disclaim: the author clos- } \\
\text { es off a dialogic alternative }\end{array}$} & $\begin{array}{l}\text { Deny: the author rejects an alternative (thus presupposing } \\
\text { that the alternative exists) }\end{array}$ \\
\hline & & $\begin{array}{l}\text { Counter: the author rejects a previous utterance, thereby } \\
\text { negating it as an alternative }\end{array}$ \\
\hline & \multirow[t]{3}{*}{$\begin{array}{l}\text { Proclaim: the author } \\
\text { forcefully argues for a } \\
\text { proposition }\end{array}$} & $\begin{array}{l}\text { Concur: the author overtly presents herself and the audience } \\
\text { as being in agreement }\end{array}$ \\
\hline & & $\begin{array}{l}\text { Pronounce: the author insists on the validity of a proposition, } \\
\text { implying that there is a counterargument against which in- } \\
\text { sistence is necessary }\end{array}$ \\
\hline & & Endorse: the author presumes an external source to be valid \\
\hline
\end{tabular}

Appendix 1 describes the various expansive and contractive Engagement strategies as laid out in Martin \& White (2005), using examples drawn from the three victory speeches by Donald Trump, Hillary Clinton, and Bernie Sanders that we analyze in this article.

Analyses of political language using other constructs can sometimes also be understood within the Engagement framework. For example, the previously mentioned study of Sanders's rhetorical strategy of attributing opinions to supporters or opponents is captured by what the Engagement framework labels the attribute: acknowledge or attribute: distance strategy. Similarly, Obama's use of personification or polyphony to "get another person (fictitious or, plausibly, real) to voice" the ideas in his speeches (Capone, 2010: 2966) can also be related to the attribute: acknowledge strategy in Martin and White's approach. Furthermore, Slatcher et al.'s (2007) comparison of the 2004 candidates, which evaluates what they call cognitive complexity (including tentative words and negations) can be understood in terms of the entertain and disclaim: deny Engagement strategies. However, no study so far (to the authors' knowledge) has explicitly used systemic functional linguistic analysis to examine the 2016 candidates' efforts to express identification with their audience. We therefore believe an analysis 
based on Martin and White's Engagement framework can provide a fruitful discussion of the hotly contested and groundbreaking 2016 campaign and also offer avenues for future research on political speech.

\section{METHOD}

For the purposes of this analysis, we selected three speeches: Trump's victory speech after winning the Indiana primary (and effectively winning the nomination) on May 3, 2016; Clinton's speech celebrating her victory in California primary on June 7 (likewise securing her the nomination); and Sanders's remarks after winning the New Hampshire primary in a landslide on February 10 (News Editor, 2016; Reilly, 2016; Washington Post Staff, 2016a).

Candidates' speeches may vary widely throughout the campaign in terms of their occasion, purpose, and intended audience. We chose to focus on victory speeches because they have a definable communicative purpose, offering candidates the opportunity to restate their vision and what they see as the impetus of the campaign; "they are a modern means by which political leaders define and communicate the ethos of their party" (Malkmus, 2013, p. 283). Speeches at the end of a contested primary also confront candidates with the need to appeal to their opponents' disaffected supporters. We therefore expect candidates giving victory speeches to engage in some way with the arguments and ideas that motivate their candidacy, and to make a play for votes, both by defending the views of their supporters and countering the arguments of their opponent. Victory speeches also tend to follow some broad generic patterns, making it easier to compare apples with apples (or at least apples with another form of fruit).

Having selected these three texts, we coded each utterance that contained a logical proposition of some kind as either monoglossic (bare assertions and statements with presupposition) or heteroglossic; we then used White's framework to further categorize each heteroglossic proposition (as entertain, attribute, disclaim, or proclaim, including subtypes; see Table 1). Each author coded the texts separately. All coding disagreements were discussed and resolved.

\section{RESULTS}

\section{Monoglossia vs. Heteroglossia}

For each speech, we calculated the ratio of monoglossic to heteroglossic assertions. Overall, Trump relied on bare assertions approximately as often as Clinton or Sanders, with monoglossic statements accounting for $54.28 \%$ of his total propositions. (For comparison 55\% of Clinton's utterances were monoglossic, as were 52.83\% of Sanders's.) Two percent of Trump's monoglossic statements included examples of presupposition, as did $1 \%$ of Clinton's monoglossic statements and 3\% of Sanders's.

Table 2

Summary of Engagement Moves: Monoglossia

\begin{tabular}{|l|c|c|c|}
\hline \multicolumn{1}{|c|}{ Candidate } & Monoglossic & Presuppositions $^{\star \star}$ & Heteroglossic $^{*}$ \\
\hline Trump & $54.27 \%$ & $2 \%$ & $45.73 \%$ \\
\hline Clinton & $55.00 \%$ & $1 \%$ & $45.00 \%$ \\
\hline Sanders & $52.83 \%$ & $3 \%$ & $47.17 \%$ \\
\hline
\end{tabular}

Note. ${ }^{*}$ as a percentage of all assertions. ${ }^{* \star}$ as a percentage of monoglossic assertions. 


\section{Contracting vs. Expanding}

Trump, Clinton, and Sanders all use a mix of contracting and expanding moves in their speeches, as shown in Table 3. As a percentage of all heteroglossic assertions, Sanders used contractive moves most often (41.51\%), followed by Clinton $(38.57 \%)$ and Trump (35.53\%).

Table 3

Summary of Engagement Moves: Heteroglossia

\begin{tabular}{|l|c|c|c|}
\hline \multicolumn{1}{|c|}{ Candidate } & Heteroglossic $^{\star}$ & Contractive $^{\star \star}$ & Expansive $^{\star \star}$ \\
\hline Trump & $45.73 \%$ & $77.70 \%$ & $22.30 \%$ \\
\hline Clinton & $45.00 \%$ & $85.71 \%$ & $14.29 \%$ \\
\hline Sanders & $47.17 \%$ & $88.00 \%$ & $12.00 \%$ \\
\hline
\end{tabular}

Note. *as a percentage of all assertions. **as a percentage of heteroglossic assertions.

However, as is evident from Table 4, the speakers vary in the use of their favored Engagement moves. While all three used disclaim: deny and disclaim: counter and either proclaim: pronounce or proclaim: concur (all contractive moves) on a regular basis, Trump and Sanders used disclaim: deny, proclaim: pronounce, and disclaim: counter nearly to the exclusion of other moves. Clinton, by contrast, used attribute: acknowledge (12.70\% of heteroglossic propositions) and proclaim: concur $(12.70 \%)$ more often than either of her opponents.

Table 4

Most Common Engagement Strategies

\begin{tabular}{|c|c|c|c|c|}
\hline Candidate & \multicolumn{4}{|c|}{ Frequency of Engagement Move Usage* } \\
\hline Trump & $\begin{array}{l}\text { Disclaim: deny } \\
(39.57 \%)\end{array}$ & $\begin{array}{l}\text { Proclaim: pronounce } \\
(20.14 \%)\end{array}$ & $\begin{array}{l}\text { Disclaim: counter } \\
(20.14 \%)\end{array}$ & Entertain (13.67\%) \\
\hline Clinton & $\begin{array}{l}\text { Disclaim: deny } \\
(41.2 \%)\end{array}$ & $\begin{array}{l}\text { Disclaim: counter } \\
(19.05 \%)\end{array}$ & $\begin{array}{l}\text { Attribute: acknowledge } \\
(12.70 \%)\end{array}$ & $\begin{array}{l}\text { Proclaim: concur } \\
(12.70 \%)\end{array}$ \\
\hline Sanders & $\begin{array}{l}\text { Disclaim: deny } \\
(53.33 \%)\end{array}$ & $\begin{array}{l}\text { Proclaim: pronounce } \\
(16 \%)\end{array}$ & $\begin{array}{l}\text { Disclaim: counter } \\
(14.67 \%)\end{array}$ & $\begin{array}{l}\text { Attribute: acknowledge } \\
(6.67 \%)\end{array}$ \\
\hline
\end{tabular}

Note. *as a percentage of heteroglossic assertions.

\section{DISCUSSION}

\section{Monoglossia}

Bare Assertions. Just over half the statements in all three speeches were monoglossic. While more analysis is needed to determine whether this is characteristic of victory speeches or political speeches in general, this rate of monoglossia may reflect the speaker's felt need to be assertive and take the opinions of the audience for granted.

While Trump offers monoglossic statements with approximately the same frequency as Clinton or Sanders, he is more prone to long strings of monoglossic statements without the interruption of a heteroglossic assertion. This has the effect of presenting a stream of assertions that rarely recognizes or references alternative positions. Many sections of Trump's speech, indeed, are almost entirely monoglossic, interspersed only with disclaim: deny moves:

(1) We've been losing all the time. We lose with our military. We can't beat ISIS. We lose with trade. We lose with borders. We lose everything. We're not going to lose. We're going to start winning again and we're going to win big league. 
Excerpts like these are construed as one categorical voice that the audience is expected to believe, one position that the listener agrees with. This single-voicedness in Trump's discourse resembles the language of sermons, which are often characterized by simple sentence structure, common word choice, and repetition. The lack of reference to other voices also contributes to the plainness and simplicity of his deliberations, perhaps reminding the listener of powerful political slogans of the past.

Presuppositions. All three candidates we analyzed take some information for granted and indicate assumptions they expect their audience to share. For example, throughout his New Hampshire victory speech, Bernie Sanders presented controversial arguments as 'old news'.

(2) Tonight, we served notice to the political and economic establishment of this country that the American people will not continue to accept a corrupt campaign finance system that is undermining American democracy, and we will not accept a rigged economy in which ordinary Americans work longer hours for lower wages, while almost all new income and wealth goes to the top $1 \%$.

In this excerpt, Sanders's proposition can be simplified as The American people will not continue to accept the state of affairs. He makes no explicit argument about what the state of affairs actually is, instead presenting that information as beyond debate. In this case, Sanders takes for granted the following propositions:

- the campaign finance system is corrupt;

- the campaign finance system is undermining American democracy;

- the economy is rigged;

- in this economy, ordinary Americans work longer hours for lower wages.

Sanders also uses nominalizations to encode his implications of shared understanding:

(3) When we talk about transforming America, it means ending the disgrace of this country having more people in jail than any other country in the world, disproportionately African-American, and Latino.

The implicature here consists in the linkage of a nominalized phrase ("this country having more people in jail than any other country in the world") and an evaluation (a "disgrace"). Sanders is speaking to those who agree with him that America's jails are too full - a common belief, but by no means a universal one.

Clinton takes propositions for granted less often than Sanders, but she does so in a similar way. In her California speech, one instance of assuming shared understandings occurs in the context of the contrasting propositions we have seen before in Clinton's speeches:

(4) We believe we need to help young people struggling with student debt - not pile more on to our national debt with giveaways to the super-wealthy. We believe we need to make America the clean energy superpower of the 21 st century — not insist that climate change is a hoax.

This formulation assumes agreement that "giveaways to the super-wealthy [are piling] more on to our national debt". Both Sanders and Clinton take for granted propositions that their voters can fairly easily be expected to hold. (While it is not universally 
acknowledged, for example, that climate change is not a hoax, Democratic voters can probably be counted on to hold this view [Gallup, 2016].)

The question then becomes, why include beliefs to which your audience already subscribes? Simon-Vandenbergen et al. (2007) argue that taken-for-granted expressions have an important rhetorical function:

[S]peakers use them for presenting non-shared and even highly contested propositions as if they were shared knowledge. The effect is on the one hand that solidarity is confirmed with those who share the speakers' viewpoint and on the other hand that those who hold alternative opinions are put into a position where more interactive work needs to be done if they want to challenge the speaker's views. (p. 61)

Trump appears to share this view, as he also uses taken-for-granted formulations though sometimes in a different way from Sanders or Clinton. On occasion, Trump does follow a similar strategy to Sanders in using highly freighted words to encode background information:

(5) And we're going to have to take out ISIS and we're going to have to take them out fast. We can't allow that cancer to continue. We cannot allow it to continue.

The analogy here, one also employed at various times by President Obama and Defense Secretary Ashton Carter, is that ISIS shares essential characteristics with cancer that is, it is dangerous, constantly growing if unchecked, foreign to its host region, and an existential threat.

Other shared assumptions Trump invokes, however, are more difficult to parse. He often implies an understanding he and his audience have in common, without spelling out what he means.

(6) You look at some of our airports; it's third world.

(7) You look at what's going on. They want jobs.

Each of these asides seems to be making some kind of assertion, but it is not immediately clear what is meant. What about America's airports does Trump see as emblematic of a third world country? What is "going on" in Excerpt 7? Despite this vagueness, however, Trump's direct address to his audience (You look at...) implies he believes that his audience understands what he means.

In other speeches, Trump has followed a similar pattern:

(8) We don't win on trade. You look at what China's doing to us, what Japan does to us, what Mexico is just killing us at the border — at the border and with trade. Mexico is killing us - absolutely. (Washington Post Staff, 2016b)

In this excerpt, it is not clear what trade policies Trump opposes on the part of China, Japan, or Mexico, nor is it clear that he needs to spell them out. By using the You look at phrasing, Trump refers his audience to trade policies they are already unhappy about - and implicitly assumes that they already know enough about those policies to be incensed. The idea that unfavorable trade policies are damaging American economic power and job growth is taken as so far beyond argument that it is not even stated explicitly. 
In this light, an observation from Simon-Vandenbergen et al. takes on new relevance: "Most importantly however, the tactic has value as a rhetorical device which creates a forceful utterance and as such contributes to the image which politicians wish to project for themselves, i.e. that of someone "in the know"' (2007, p. 66). Trump, in these excerpts, suggests that both he and his audience have special knowledge they are aware of 'what's going on,' of 'what China's doing to us,' in a way that others in the political arena do not understand. Trump does not need to spell out what exactly he is taking for granted to take advantage of this rhetorical effect; indeed, keeping things vague may be more useful for him. By inviting his audience to 'look at' the problem as they see it, he can convince listeners with potentially widely varying opinions that he is in solidarity with them all.

\section{Heteroglossia}

As mentioned above, while each candidate makes heteroglossic statements at similar rates, they differ markedly with regard to the use of specific heteroglossic moves and ways they are combined.

Disclaim: Deny. The disclaim: deny move differs from a bare assertion only in that, by denying a proposition, it implicitly admits the existence of that proposition. While being, therefore, heteroglossic, it still has the effect of closing off debate. Trump often intersperses denials with monoglossic bare assertions and repetitions, as in the following excerpts:

(9) Not going to happen anymore, folks. Not going to happen anymore. We're going to bring back our jobs and we're going to keep our jobs. We're not going to let companies leave.

(10) We don't need the credit because we're going after Hillary Clinton. She will not be a great president. She will not be a good president. She will be a poor president.

Linguistically, the disclaim: deny move is realized by a profusion of words like no, not, don't, etc., rather than countering prepositions such as however, but, that said, etc. Appearing intermixed with monoglossic statements, disclaim: deny as used by Trump may strengthen the perception of his language as rhetorically more straightforward, forceful, and direct, or even truthful.

While Clinton uses disclaim: deny at a relatively higher rate than Trump, she employs it more often in combination with other Engagement moves. In many cases, she sets up contrasts between herself and Trump using disclaim: deny and follows up with either disclaim: counter or proclaim: concur to propose her own views in opposition to his.

(11) It's clear that Donald Trump doesn't believe [attribute: acknowledge; disclaim: deny] we are stronger together. (...) Well, we believe we should lift each other up [proclaim: concur: affirm], not tear each other down [disclaim: deny]. We believe we need to give Americans a raise [proclaim: concur: affirm] — not complain that hardworking people's wages are too high [disclaim: deny]. We believe we need to help young people struggling with student debt [proclaim: concur: affirm] — not pile more on to our national debt with giveaways to the super-wealthy [disclaim: deny]. We believe we need to make America the clean energy superpower of the 21st century [proclaim: concur: affirm] - not insist that climate change is a hoax [disclaim: deny]. 
While Trump uses disclaim: deny to continue hammering a point home, Clinton employs it as part of a mix of Engagement moves in order to constantly defend her own views and highlight the contrast between herself and Trump.

Like his opponents, Sanders uses the disclaim: deny move most often out of all the heteroglossic strategies he employs. However, like Clinton, he often interweaves this move with many others in a way that differs sharply from Trump's style.

(12) In my view [entertain] under President Obama's leadership, the Affordable Care Act has been an important step forward, no question about it [proclaim: pronounce]. But [disclaim: counter] we can, and must, do better. Twenty-nine million Americans should not remain uninsured [disclaim: deny], an even greater number should [not] [disclaim: deny] remain under-insured with large deductibles and co-payments [disclaim: deny]. We should not [disclaim: deny] be paying by far the highest prices in the world for prescription drugs at a time - listen to this [proclaim: pronounce], when the top three drug companies in this country made $\$ 45$ billion dollars in profit last year. That is an obscenity, and let me tell you something [proclaim: pronounce], when we make it to the White House, the pharmaceutical industry will not [disclaim: deny] continue to rip off the American people. (...)

My friends, we all know [proclaim: concur: affirm]. that we live in a dangerous and complex world. As president I will defend this nation, but [disclaim: counter] I will do it responsibly. I voted against the war in Iraq, and that was the right vote. While [proclaim: concur: affirm] we must be relentless in combating terrorists who would do us harm, we cannot [disclaim: deny], and should not [disclaim: deny] be the policeman of the world. Nor [disclaim: counter] should we bear the burden of fighting terrorism alone.

This passage illustrates a striking contrast to Trump. While Sanders's tone occasionally seems to veer into Trumpian territory (e.g., "Listen to this," "Let me tell you something"), this paragraph follows an Engagement schema Trump rarely uses. First, Sanders entertains or asserts a proposition meant to appeal to Democrats more broadly (one with which his most fervent supporters might disagree): "the Affordable Care Act has been an important step forward, no question about it". He then counters the idea with his own view. Sanders does this again in the next paragraph, balancing the need to be "relentless" (again, his dovish supporters might quibble with him) with a rejection of the idea of being the world's "policemen". Trump rarely introduces his assertions by entertaining or acknowledging opposing views.

In general, Trump relies on a narrower use of disclaim: deny than either Clinton or Sanders, which manifests itself linguistically in a narrower array of markers of agreement or disagreement.

Proclaim: Pronounce. The proclaim: pronounce move, realized in intensifying, definitive asides (e.g., let me tell you, it is clear) or as imperatives to the audience (e.g., remember this, don't forget this, let us do this) is perhaps the most characteristic of Trump's speeches in general, accounting for over $20 \%$ of his heteroglossic assertions. This move is counted as heteroglossic according to what might be called the 'the lady doth protest too much' theory; by defending a proposition so forcefully, the speaker implies that there is a counter-argument against which it needs defending. That said, the proclaim: pronounce move, like disclaim: deny, has the effect of restricting space for argument; by using this move, the speaker indicates that debate on the subject should be closed. 
The following excerpt illustrates one way in which Trump peppers his otherwise monoglossic assertions with pronounce moves:

(13) Let me tell you, the miners in West Virginia and Pennsylvania which was so great to me last week and Ohio and all over, they're going to start to work again. Believe me. You're going to be proud again to be miners.

Over the course of the Indiana speech, Trump uses some variation on "Let me tell you" (e.g., "I have to tell you", "I will tell you") seven times. While this move works to close off debate, it may also help Trump to foster a more immediate relationship between himself and his audience. Since it is often realized linguistically as an imperative and a second person pronoun, it enhances the impression that Trump is speaking directly to the listener.

Entertain. The entertain move generally has the effect of opening up dialogic space, by proposing an idea with which some listeners might agree; it is often realized linguistically by the use of modal verbs (may, might, could, etc.), other hedges (e.g., it seems), or mental processes (e.g., I think, I believe).

Trump uses entertain relatively infrequently (fourth most of any Engagement strategy). However, while Clinton and Sanders use the entertain move in order to introduce a political argument that they then counter (see Excerpts 11 and 12), Trump most often uses entertain when discussing election results and poll numbers, in situations in which the topic under debate is not whether he is winning, but by how much:

(14) They think it was probably $\$ 8$ million was spent against me and we spent $\$ 900,000$. So, I mean, to me that's the way it's supposed to be.

(15) I think that might actually be more and better than getting $62 \%$ in New York.

(16) He [Republican National Committee chair Reince Priebus] had 17 egos and now I guess he's down to one. I don't know. Is there a second? I mean, is there a second? I don't know.

Trump does also use entertain to hedge a stance that he otherwise describes in hardline terms:

(17) Her [Clinton's] husband signed perhaps in the history of the world the single worst trade deal ever done. It's called NAFTA.

Here, too, while Trump opens up space for his audience to dissent, it would be disagreement only in degree; he admits only that NAFTA might not be the very worst trade deal in humanity's history ${ }^{1}$. Excerpt 17 , however, is an exception to the trend; all but two of Trump's uses of entertain in this speech have to do not with arguments he is making, but with poll numbers or other trivia related to what we might call political throat-clearing (e.g., 'but I actually think he [Trump's son-in-law Jared Kushner] likes politics"). Trump's heavy use of entertain in a way that does not engage any political arguments therefore somewhat inflates the raw numbers of expansive dialogic strategies he uses.

1 Trump's formulation is strikingly similar to one of the examples of entertain given in Martin \& White (2005), who quote a 2001 edition of the Sunday Express passing judgment on the prime minister as follows: "In fact it was probably the most immature, irresponsible, disgraceful and misleading address ever given by a British Prime Minister" (p. 105). 
Proclaim: Concur: Affirm. The proclaim: concur move marks a point of contrast between Clinton and Trump. Rather than simply stating her case with proclaim: pronounce, Clinton often attributes her arguments to supporters of her campaign and (implicitly) former Sanders supporters:

(18) We all believe that America succeeds when more people share in our prosperity; when more people have a voice in our political system; when more people can contribute to their communities. We believe that cooperation is better than conflict, unity is better than division, empowerment is better than resentment, and bridges are better than walls. It's a simple but powerful idea. We believe that we are stronger together. And the stakes in this election are high. And the choice is clear.

In this passage, Clinton both defends discrete arguments that her campaign aims to advance ("America succeeds when more people share in our prosperity"; "cooperation is better than conflict") and simultaneously makes an appeal for the support of erstwhile Sanders supporters by asserting common agreement on these points. The contentious Democratic party primary left many left-leaning Sanders voters, who might otherwise have agreed with Clinton on many issues, skeptical of her candidacy because of her distance from the Vermont senator on some policy issues and the vitriol each candidate deployed against the other. With proclaim: concur moves like these, Clinton implicitly identifies those Sanders voters as her audience, reminding them that they may not have voted for her but still share these views. Trump uses this move much less often (it accounts for less than three percent of his heteroglossic statements).

This analysis indicates that Trump differs sharply with both Clinton and Sanders in the way he employs audience engagement strategies. While all of the candidates use disclaim: deny, Trump follows that move up with alternatives (via disclaim: counter or attribute: acknowledge) less than Clinton does. While all of the candidates use proclaim moves, Trump relies almost exclusively on proclaim: pronounce. Clinton, on the other hand, uses proclaim: concur: affirm/concede, which takes the opinions of the audience into consideration to a much greater extent.

These differences lead to striking contrasts in linguistic realizations. In general, the strategies preferred by Trump sketch out a discourse that relies on repetitive language (e.g., no, not, let me tell you) and chains of shorter sentences that reiterate and reinforce each other rather than forming interlocking parts of a cohesive paragraph. By contrast, Clinton's and Sanders's reliance on complementary Engagement strategies lends their speeches a more elaborate, written-like quality.

\section{CONCLUSION}

The question, then, is what relevance these linguistic and rhetorical differences may have for Trump's appeal. This question will probably occupy political scientists and linguists for years, and we do not propose to answer it comprehensively in just 7,000-odd words. While the focus on three campaign speeches is a clear limitation of the study and a more representative corpus would add more value to its results, this analysis does highlight stark differences between Trump's style and that of two more mainstream politicians - differences which, we believe, would hold if a wider swath of speeches from Trump and previous presidential nominees were analyzed using this framework. Future research might draw from a deeper pool of candidate speeches and employ 
factor analysis to flesh out a more complete description of various candidates' use of Engagement. These differences may help explain Trump's enduring popularity with a not insignificant segment of the American electorate.

In general, Trump's heteroglossic language is simpler and more straightforward and forceful than his opponents', while his monoglossic statements incorporate more vaguely phrased shared assumptions to connect with his base. As noted earlier, while Trump employs heteroglossic moves approximately as often as Clinton or Sanders do, he relies on a narrower slate of these moves and often deploys the same ones in sequence. This lends Trump's speeches a more repetitive effect, which can work to the speaker's advantage; repetition can give the speaker an air of authority, provoking an unconscious response of support among his listeners (Lakoff, 2016). Journalists such as James Fallows have pointed out that simplicity often represents strength in political addresses, particularly when delivered verbally:

In political language, plainness is powerful. "Of the people, by the people, for the people." "Ask not what your country can do for you." "I have a dream." This is especially so for language designed to be heard, like speeches and debate exchanges, rather than read from a page. People absorb and retain information in smaller increments through the ear than through the eye. Thus, the classic intonations of every major religion have the simple, repetitive cadence also found in the best political speeches. "In the beginning." "And it was good." "Let us pray." (Fallows, 2016)

Trump's selection of simplistic, repetitive assertions and denials, exemplified by eschewing many Engagement moves in favor of disclaim: deny, may remind his audience of these powerful political volleys from the past. One of the most famous lines from a political debate, indeed - "Senator, I served with Jack Kennedy. I knew Jack Kennedy. Jack Kennedy was a friend of mine. Senator, you're no Jack Kennedy." with its melding of monoglossia with a disclaim: deny move, sounds almost like it could have come from Trump (October 5, 1988 Debate Transcripts, 2015).

The vagueness of some of Trump's assertions may also have helped him reach new audiences who express grievances that other politicians would be loath to air; as Hillbilly Elegy author J.D. Vance argued in an interview, "these people - my people are really struggling, and there hasn't been a single political candidate who speaks to those struggles in a long time" (Dreher, 2016). This may seem paradoxical: Clinton and Sanders, after all, both use a wider array of both expansive and contractive moves in order to broaden their support (see Excerpt 11, in which Sanders uses entertain and disclaim: counter to construe an audience broader than his most die-hard supporters; or Excerpt 18, in which Clinton uses proclaim: concur to implicitly include Sanders supporters in 'we'-statements). In contrast to Clinton's and Sanders's presentations, Trump's speeches seem not to have outreach to potential new supporters as their goal; instead, he aims to foster solidarity among those who already agree with him. There is already anecdotal evidence that Trump's supporters do not need to be persuaded that the propositions he defends are true; according to a journalist at Vox, "Trump's audience finishes his sentences for him, [and] the blanks are filled with sentiments that resonate: fears of joblessness, worries about the United States losing its status as a major world power, concerns about foreign terrorist organizations" (Golshan, 2016). The linguistic evidence from these speeches points in the same direction: Trump often bakes 
shared assumptions into his monoglossic assertions in a way that leaves it unclear exactly what he means. His audience, however, is meant to get the point-one that usually relates to general dissatisfaction with Democratic policies-without his help, as he implies with proclaim: pronounce formulations like "You look at what's going on". The vagueness of the shared assumptions, whose existence Trump implies without always being specific, suggests that his audience already knows what he means.

Our analysis suggests that Trump might simply have a different understanding of the goal of a political speech than most mainstream politicians. While Clinton and Sanders use Engagement strategies in order to defend their arguments and broaden their potential audience, Trump's speeches seem designed to assert, as forcefully as possible, the precepts with which his audience already agrees, while leaving certain assertions vague to allow his audience to fill in the blanks.

(C) Marianna Ryshina-Pankova, Justin Quam, 2016

\section{REFERENCES}

Anderson, K.V. (2002). From spouses to candidates: Hillary Rodham Clinton, Elizabeth Dole, and the gendered office of US president. Rhetoric \& Public Affairs, 5(1), 105-132.

Austin, J. L. (1975). How to do things with words. Oxford University Press.

Barreto, M.A., Redlawsk, D., \& Tolbert, C.J. (2009). Measuring respondent agreement/disagreement with framing experiments: Race, religion and voting against Barack Obama in 2008. Paper presented at the Annual Meeting of the American Political Science Association, September 3-6, 2009, Toronto, ON, Canada.

Bierman, N. (2016, July 20). Here are the places where Donald Trump and the Republican Party disagree. Los Angeles Times. Accessed 10 December 2016 at http://www.latimes.com/politics/ la-na-pol-trump-gop-positions-20160720-snap-htmlstory.html.

Bligh, M., Merolla, J., Schroedel, J.R., \& Gonzalez, R. (2010). Finding her voice: Hillary Clinton's rhetoric in the 2008 presidential campaign. Women's Studies, 39(8), 823-850.

Capone, A. (2010). Barack Obama's South Carolina speech. Journal of Pragmatics, 42(11), 29642977.

Catalano, T. (2011). Barack Obama: A semiotic analysis of his Philadelphia speech. Issues in Political Discourse Analysis, 8(1), 47-74.

Chang, G.C., \& Mehan, H.B. (2006). Discourse in a religious mode: The Bush administration's discourse in the War on Terrorism and its challenges. Pragmatics, 16(1), 1-23.

Clark, C. (2007, June 25). Drew Westen's 'Political Brain' gets Democratic candidates thinking. Emory Report. Accessed 9 December 2016 at https://www.emory.edu/EMORY_REPORT/erarchive/ 2007/June/June\%2025/Westen.htm.

Degani, M. (2016a). Endangered intellect: a case study of Clinton vs Trump campaign discourse. Iperstoria - Testi Letterature Linguaggi, 8, 131-145.

Degani, M. (2016b). An investigation of American opposing political cultures in the speeches of Barack Obama and John McCain. Accessed 10 December 2016 at http://edipuglia.it/wp-content/ uploads/2016/08/Degani.pdf.

Dreher, R. (2016, July 22). Trump: Tribune of poor white people. The American Conservative. Accessed 3 September 2016 at http://www.theamericanconservative.com/dreher/trump-us-politicspoor-whites. 
Fallows, J. (2016, October). When Donald meets Hillary. The Atlantic. Accessed 24 September 2016 at http://www.theatlantic.com/magazine/archive/2016/10/who-will-win/497561/

Gallup. (2016). Americans believe 2015 was record-warm, but split on why. Gallup. Accessed 13 December 2016 at http://www.gallup.com/poll/190319/americans-believe-2015-record-warm-splitwhy.aspx?g_source=CATEGORY_CLIMATE_CHANGE\&g_medium=topic\&g_campaign=tiles.

Golshan, T. (2016, August 18). Donald Trump's strange speaking style, as explained by linguists. Vox. Accessed 3 September 2016 at http://www.vox.com/2016/8/18/12423688/donald-trumpspeech-style-explained-by-linguists.

Hall, K., Goldstein, D.M., \& Ingram, M.B. (2016). The hands of Donald Trump: Entertainment, gesture, spectacle. HAU: Journal of Ethnographic Theory, 6(2), 71-100.

Halliday, M.A.K., \& Matthiessen, C.M.I.M. (2004). An introduction to functional grammar. London: Arnold.

Hoel, N.S. (2016). Challenging social class in American political discourse: Bernie Sanders, Occupy Wall Street, and the new discourse of inequality. (Unpublished MA thesis). Oslo: University of Oslo.

Knoll, B.R., Redlawsk, D.P., \& Sanborn, H. (2011). Framing labels and immigration policy attitudes in the Iowa caucuses: "Trying to out-Tancredo Tancredo". Political Behavior, 33(3), 433-454.

Lexicon Valley. (2015, July 31). Help us diagram this sentence by Donald Trump! Slate Magazine. Accessed 10 December 2016 at http://www.slate.com/blogs/lexicon_valley/2015/07/31/donald_ trump_this_run_on_sentence_from_a_speech_in_sun_city_south_carolina.html.

Iyengar, S. (2005). Speaking of values: The framing of American politics. The Forum, 3(3), $1-8$.

Kruse, M., \& Weiland, N. (2015, May 5). Donald Trump's greatest self-contradictions. Politico. Accessed 3 September 2016 at http://www.politico.com/magazine/story/2016/05/donald-trump2016-contradictions-213869.

Lakoff, G. (2004). Don't think of an elephant! Know your values and frame the debate. the essential guide for progressives, including post-election updates. Chelsea, VT: Chelsea Green Publishing.

Lakoff, G. (2016, July 23). Understanding Trump. [Blog post]. Accessed 13 December 2016 at https://georgelakoff.com/2016/07/23/understanding-trump-2.

Liberman, M. (2016a, August 16). The rhetorical style of spontaneous speech. [Blog post]. Language Log. Accessed 3 September 2016 at http://languagelog.ldc.upenn.edu/nll/?p=27515.

Liberman, M. (2016b, August 15). The em-dash candidate. [Blog post]. Language Log. Accessed 3 September 2016 at http://languagelog.ldc.upenn.edu/nll/?p=27479.

Libit, D. (2016, August 15). Transcribers' agony: Frustrated not by what Trump says but how he says it. CNBC. Accessed 13 December 2016 at http://www.cnbc.com/2016/08/15/transcribers-agonyfrustrated-not-by-what-trump-says-but-how-he-says-it.html.

Malkmus, T. (2013). "Marco and micro, quantitative and qualitative: An integrative approach for analyzing (election night) speeches". In Discourse approaches to politics, society and culture. Analyzing genres in political communication: Theory and practice (pp. 267-296). Philadelphia/Amsterdam: John Benjamins.

Martin, J.R., \& White, P.R.R. (2005). The language of evaluation. London: Palgrave Macmillan.

Miller, D.R. (2002). Multiple judicial opinions as specialized sites of ENGAGEMENT: conflicting paradigms of valuation and legitimation in Bush v. Gore 2000. In M. Gotti, D. Heller, \& M. Dossena (Eds.), Conflict and negotiation in specialized texts (pp. 119-141). Bern: Peter Lang. 
Miller, D.R. (2004). “...to meet our common challenge”: ENGAGEMENT strategies of alignment and alienation in current US international discourse. Textus, 18(1), 39-62.

News Editor. (2016, May 4). Transcript: Donald Trump's remarks after winning the Indiana primary - Part 1 | What The Folly?!. Whatthefolly.com. Accessed 14 December 2016 at http://www.whatthefolly.com/2016/05/04/transcript-donald-trumps-remarks-after-winningthe-indiana-primary-part-1.

October 5, 1988 Debate Transcripts. (2015). Commission on Presidential Debates. Accessed 14 December 2016 at http://www.debates.org/index.php?page=october-5-1988-debate-transcripts.

Parker, A., \& Haberman, M. (2016, May 28). Donald Trump's campaign stumbles as it tries to go big. The New York Times. Accessed 10 December 2016 athttp:/www.nytimes.com/2016/05/28/ us/politics/donald-trump-campaign.html.

Pennebaker, J.W., Slatcher, R.B., \& Chung, C.K. (2005). Linguistic markers of psychological state through media interviews: John Kerry and John Edwards in 2004, Al Gore in 2000. Analyses of Social Issues and Public Policy, 5(1), 197-204.

Pullum, G. (2015, August 5). Trump's aphasia. [Blog post]. Language Log. Accessed 3 September 2016 at http://languagelog.ldc.upenn.edu/nll/?p=20490.

Rappeport, A., \& Haberman, M. (2016, June 30). How Donald Trump keeps changing his mind on abortion, torture and banning Muslims. The New York Times. Accessed 3 September 2016 at http://www.nytimes.com/2016/06/30/us/politics/donald-trump-flip-flop.html.

Reilly, K. (2016). Read Hillary Clinton's historic primary victory speech. TIME.com. Accessed 14 December 2016 at http://time.com/4361099/hillary-clinton-nominee-speech-transcript.

Savoy, J. (2016). Analysis of the style and the rhetoric of the 2016 US presidential primaries. Accessed 13 December 2016 at https://www.researchgate.net/profile/Jacques_Savoy/publication/ 310674208_Analysis_of_the_Style_and_the_Rhetoric_of_the_2016_US_Presidential_Primaries/ links/58353f1908ae102f07397219.pdf.

Silver, N. (2015, Nov. 23). Dear media, stop freaking out about Donald Trump's polls. FiveThirtyEight. Accessed 10 December 2016 at http://fivethirtyeight.com/features/dear-media-stop-freakingout-about-donald-trumps-polls.

Slatcher, R.B., Chung, C.K., Pennebaker, J.W., \& Stone, L.D. (2007). Winning words: Individual differences in linguistic style among US presidential and vice presidential candidates. Journal of Research in Personality, 41(1), 63-75.

Sparks, A. (2009). Minstrel politics or "He speaks too well": Rhetoric, race, and resistance in the 2008 presidential campaign. Argumentation and Advocacy, 46(1), 21-38.

Washington Post Staff. (2016a, February 20). The transcript of Bernie Sanders's victory speech. The Washington Post. Accessed 14 December 2016 at https://www.washingtonpost.com/ news/post-politics/wp/2016/02/10/the-transcript-of-bernie-sanderss-victory-speech/?utm _ term $=.5 \mathrm{a} 96 \mathrm{~b} 1148168$.

Washington Post Staff. (2016b, February 20). Transcript: Trump's victory speech after the South Carolina GOP primary. The Washington Post. Retrieved 13 December 2016, from https://www.washingtonpost.com/news/post-politics/wp/2016/02/20/transcript-donald-trumpsvictory-speech-after-the-south-carolina-gop-primary/?utm_term $=.808 \mathrm{a} 763 \mathrm{f} 71 \mathrm{~b} 4$.

Westen, D. (2008). The political brain: The role of emotion in deciding the fate of the nation. Public Affairs.

White, P.R.R. (2003). Beyond modality and hedging: A dialogic view of the language of intersubjective stance. Text, 23(2), 259-284.

White, P.R.R. (2015) Appraisal and the resources of intersubjective stance. Accessed 12 April 2016 at http://languageofevaluation.info/appraisal/engagement/engagementlatest.doc. 
APPENDIX

Engagement System Network with Examples

\begin{tabular}{|c|c|c|c|c|}
\hline $\begin{array}{c}\text { Dialogic } \\
\text { Role }\end{array}$ & Type & Subtype & Linguistic markers & Examples \\
\hline \multirow[t]{3}{*}{$\begin{array}{l}\text { Expan- } \\
\text { sive }\end{array}$} & $\begin{array}{l}\text { Entertain: the } \\
\text { author holds } \\
\text { out a dialogic } \\
\text { alternative as } \\
\text { possible }\end{array}$ & & $\begin{array}{l}\text { Hedges (I think...; it } \\
\text { seems...; possibly; ap- } \\
\text { parently) } \\
\text { Pseudo-questions }\end{array}$ & $\begin{array}{l}\text { In my view, under President } \\
\text { Obama's leadership, the Afford- } \\
\text { able Care Act has been an im- } \\
\text { portant step forward.... (Sanders) } \\
\text { Her husband signed perhaps in } \\
\text { the history of the world the sin- } \\
\text { gle worst trade deal ever done. } \\
\text { (Trump) }\end{array}$ \\
\hline & \multirow{2}{*}{$\begin{array}{l}\text { Attribute: the } \\
\text { author posits } \\
\text { another voice } \\
\text { as the source } \\
\text { of the asser- } \\
\text { tion }\end{array}$} & $\begin{array}{l}\text { Distance: the author } \\
\text { presents an external } \\
\text { source's voice as } \\
\text { questionable }\end{array}$ & $\begin{array}{l}\text { Verbal processes with } \\
\text { inscribed meaning that } \\
\text { suggests skepticism (e.g., } \\
\text { the defendant claims...) }\end{array}$ & $\begin{array}{l}\text { Well, my critics say, you know, } \\
\text { Bernie, that's a great idea, } \\
\text { you're into all this free stuff. } \\
\text { (Sanders) }\end{array}$ \\
\hline & & $\begin{array}{l}\text { Acknowledge: the } \\
\text { author presents an } \\
\text { external source's } \\
\text { voice without explicit } \\
\text { endorsement, leaving } \\
\text { room for countervail- } \\
\text { ing views }\end{array}$ & $\begin{array}{l}\text { Verbal processes without } \\
\text { inscribed meaning (e.g., } \\
\text { say, state, argue) } \\
\text { Referential prepositions } \\
\text { (e.g., according to, in) }\end{array}$ & $\begin{array}{l}\text { What the American people are } \\
\text { saying }(\ldots) \text { is that we can no } \\
\text { longer continue to have a cam- } \\
\text { paign finances system in which } \\
\text { Wall Street and the billionaire } \\
\text { class are able to buy elections. } \\
\text { (Sanders) }\end{array}$ \\
\hline \multirow[t]{5}{*}{$\begin{array}{l}\text { Contrac } \\
\text { tive }\end{array}$} & \multirow[t]{2}{*}{ Disclaim } & $\begin{array}{l}\text { Deny: the author re- } \\
\text { jects an alternative } \\
\text { (thus presupposing } \\
\text { that the alternative } \\
\text { exists) }\end{array}$ & Negation & $\begin{array}{l}\text { We will not accept a rigged } \\
\text { economy in which ordinary } \\
\text { Americans work longer hours } \\
\text { for lower wages. (Sanders) } \\
\text { Not going to happen anymore, } \\
\text { folks. Not going to happen an- } \\
\text { ymore. (Trump) }\end{array}$ \\
\hline & & $\begin{array}{l}\text { Counter: the author } \\
\text { rejects a previous } \\
\text { utterance, thereby } \\
\text { negating it as an al- } \\
\text { ternative }\end{array}$ & $\begin{array}{l}\text { Conjunctions (e.g., but, } \\
\text { however, despite that) }\end{array}$ & $\begin{array}{l}\text {...But don't let anyone tell you } \\
\text { that great things can't happen } \\
\text { in America. (Clinton) }\end{array}$ \\
\hline & \multirow[t]{3}{*}{ Proclaim: } & $\begin{array}{l}\text { Concur: the author } \\
\text { overtly presents her- } \\
\text { self and the audience } \\
\text { as being in agree- } \\
\text { ment }\end{array}$ & & $\begin{array}{l}\text { Concede: So yes, yes, there } \\
\text { are still ceilings to break - for } \\
\text { women and men, for all of us. } \\
\text { But don't let anyone tell you } \\
\text { that great things can't happen } \\
\text { in America. (Clinton) } \\
\text { Affirm: We all believe that } \\
\text { America succeeds when more } \\
\text { people share in our prosperity; } \\
\text { when more people have a voice } \\
\text { in our political system; when } \\
\text { more people can contribute to } \\
\text { their communities. (Clinton) }\end{array}$ \\
\hline & & $\begin{array}{l}\text { Pronounce: the author } \\
\text { insists on the validity } \\
\text { of a proposition, im- } \\
\text { plying that there is a } \\
\text { counterargument } \\
\text { against which insist- } \\
\text { ence is necessary }\end{array}$ & $\begin{array}{l}\text { (e.g., It is clear that..., } \\
\text { it is incontrovertible } \\
\text { that..., let me tell you...) }\end{array}$ & $\begin{array}{l}\text { Let me tell you, the miners in } \\
\text { West Virginia and Pennsylvania } \\
\text { (...) they're going to start to work } \\
\text { again. (Trump) } \\
\text { It's clear that Donald Trump } \\
\text { doesn't believe we are stronger } \\
\text { together. (Clinton) }\end{array}$ \\
\hline & & $\begin{array}{l}\text { Endorse: the author } \\
\text { presumes an external } \\
\text { source to be valid }\end{array}$ & $\begin{array}{l}\text { Verbal processes with in- } \\
\text { scribed meaning that sug- } \\
\text { gests confidence (e.g., } \\
\text { the analysis proves...; the } \\
\text { judgment established...) }\end{array}$ & $\mathrm{n} / \mathrm{a}$ \\
\hline
\end{tabular}


Article history:

Received: 01 September 2016

Revised: 10 October 2016

Accepted: 01 November 2016

For citation:

Quam J., Ryshina-Pankova M. (2016). "Let Me Tell You...": Audience Engagement Strategies in the Campaign Speeches of Trump, Clinton, and Sanders. Russian Journal of Linguistics, 20 (4), 140-160.

\title{
Bio Note:
}

Justin Quam, PHd Student. Research interests: Second Language Acquisition, Discourse Analysis, Advanced Foreign Language Literacy Development and Instruction. Contact Information: http://explore.georgetown.edu; e-mail: jq89@georgetown.edu

Marianna Ryshina-Pankova, DSc, Associate Professor, Director of curriculum in the German department at Georgetown at Georgetown University (Washington D.C., USA). Research interests: Second Language Acquisition, Discourse Analysis, Advanced Foreign Language Literacy Development and Instruction. Contact Information: http://explore.georgetown.edu; e-mail: ryshinam@georgetown.edu

\section{«ВОТ ЧТО Я ВАМ СКАЖУ...»: СТРАТЕГИИ МАНИПУЛИРОВАНИЯ АУДИТОРИЕЙ В ПРЕДВЫБОРНОЙ РЕЧИ ТРАМПА, КЛИНТОН И САНДЕРСА}

\author{
Джастин Куам, Марианна Рышина-Панькова \\ Университет Джорджтаун \\ 20057, Вашингтон, США, $37^{\text {th }}$ and $O$ Streets
}

Во время предвыборной кампании 2016 г. кандидат на пост президента Дональд Трамп удивил своей способностью поддерживать популярность несмотря на неподобающие и часто оскорбительные высказывания. Вероятно, Трамп увеличил свои шансы на победу, обращаясь к тому значительному сегменту электората, которые не встали на сторону других кандидатов. В одной телевизионной программе было сказано: «Люди пытались дискредитировать Трампа, но ничего не вышло он все равно нравился избирателям». Как утверждают исследователи (Miller 2002; 2004), благодаря системно-функциональному лингвистическому анализу (Halliday \& Matthiessen, 2004) можно выявить конкретные стратегии, которыми пользуются политики для подкрепления своих аргументов и побуждения аудитории поддержать их. В данной статье мы опираемся на модель взаимодействия (Engagement framework) (White, 2003; Martin \& White, 2005), основанную на системно-функциональном анализе для определения приемов, с помощью которых кандидаты на пост президента 2016 г. привлекали симпатии избирателей. Проведенный нами анализ речи Дональда Трампа, Хиллари Клинтон и Берни Сандерса показал совершенно разные способы взаимодействия с аудиторией в плане использования экспансивной и контрактивной диалогических стратегий, определения целевой аудитории и общих взглядов. В выступлениях Трампа прослеживается тенденция вести диалог в узком диалогическом пространстве, в котором аудитория по определению с ним согласна, в то время как его соперники часто сочетают контрактивную и экспансивную аргументативные стратегии и ведут более открытый диалог с аудиторией, чьи идеи они разделяют. В статье исследуется, как каж- 
дый из кандидатов определяет свою аудиторию и обращается к сторонникам или противникам своих политических взглядов и призывает их оказать им поддержку.

Ключевые слова: дискурс-анализ, политический дискурс, политическое выступление, коммуникативные диалогические стратегии

\section{История статьи:}

Дата поступления в редакцию: 01 сентября 2016

Дата принятия к печати: 01 ноября 2016

\section{Для цитирования:}

Quam J., Ryshina-Pankova M. (Washington DC, USA) "Let Me Tell You...": Audience Engagement Strategies in the Campaign Speeches of Trump, Clinton, and Sanders // Вестник Российского университета дружбы народов. Серия: Лингвистика. 2016. Т. 20. № 4. C. 140-160.

\section{Сведения об авторах:}

Джастин Куам, аспирант кафедры немецкого языка, Университет Джорджтаун (Вашингтон, США). Сфера научных интересов: Методика преподавания второго иностранного языка, теория дискурса, формирование грамотности, речевых навыков и умений в рамках изучения иностранного языка. Контактная информация: http://explore.georgetown.edu; e-mail: jq89@georgetown.edu

Марианна Рышина-Панькова, доктор, профессор, кафедра немецкого языка, Университет Джорджтаун (Вашингтон, США). Сфера научных интересов: Методика преподавания второго иностранного языка, теория дискурса, формирование грамотности, речевых навыков и умений в рамках изучения иностранного языка. Контактная информация: http://explore.georgetown.edu; e-mail: ryshinam@georgetown.edu 